PAEDAGOGIA ChristianA

I /23(2009) - ISSN 1505-6872

Adriana Adamska*

Kraków

\title{
Pedagogika czasu wolnego - teoria a praktyka, Trnava (Słowacja), 25-26 października 2007 roku
}

W dniach 25-26 października 2007 roku odbyła się międzynarodowa konferencja naukowa zorganizowana przez Wydział Pedagogiczny Uniwersytetu w Trnavie (Słowacja) poświęcona zagadnieniom pedagogiki czasu wolnego. Pełny temat konferencji to Pedagogika vol’ného času - teória a prax - w języku polskim: Pedagogika czasu wolnego - teoria a praktyka. W konferencji uczestniczyli prelegenci z Czech, Polski, Ukrainy oraz z różnych ośrodków naukowych na Słowacji.

Pierwsza część obrad miała charakter plenarny. Profesor E. Kratochvilová w wykładzie otwierającym nakreśliła aktualne założenia pedagogiki wolnego czasu zarówno w praktyce, jak i teorii. Jakkolwiek dyscyplina ta jest stosunkowo młodą gałęzią nauki, niemniej jej historia jest długa - sięga czasu szkół chrześcijańskich, łacińskich, poprzez renesans aż po współczesność. To, co było szczególnie podkreślone, to fakt, że pedagogika jest dyscypliną żywą - praktyka jest w niej tworzywem, które buduje teorię. Pani profesor zgłosiła również wymowne spostrzeżenie/pytanie, które domaga się żywej odpowiedzi - dlaczego na tle innych specjalistów zabierających głos w mediach oraz prezentujących różne poglądy wciąż tak niewielu jest pedagogów, jeśli w ogóle...

Część druga konferencji poświęcona była obradom w sekcjach. Sekcja, w której uczestniczyła autorka była bogata w materiał wizualny. Jedna z prelegentek przedstawiła w ramach swojego wystapienia nawet film. Pani mgr M. Imrichová jest dyrektorem największego w Unii Europejskiej przedszkola. Przedszkole to mieści się w Prešowie. Liczba jego wychowanków wynosi 270. Pani dyrektor zaprezentowała film zatytułowany Tydzień dziecięcych radości (Tydzen dietskich

* Dr Adriana Adamska, adiunkt w Katedrze Edukacji Artystycznej Wyższej Szkoły Filozoficzno-Pedagogicznej „Ignatianum” w Krakowie. 
radosti). Na Słowacji uczestnikami tak zwanych „Zielonych Szkół” są już przedszkolaki. Film opowiadał o dzieciach z tego właśnie przedszkola, które pojechały przeżyć przygodę i uczyć się w przyrodzie ${ }^{1}$. Czterdziestoosobowa grupa czterolatków spędziła pięć dni bez rodziców, z wychowawczyniami i pielęgniarką. To, co zdumiewające, to to, że wyjeżdżające dzieci bynajmniej nie płaczą z tęsknoty za domem, lecz wtedy właśnie, gdy trzeba do niego wracać.

Słowacki system szkolnictwa rozpoczyna edukację ekologiczną bardzo wcześnie. Jedną z jej form są właśnie takie wyjazdy. Warto zaznaczyć, że przygotowanie takiej inicjatywy polega nie tylko na stronie merytorycznej, lecz ma swoje oparcie także w stronie praktycznej, jaką jest na przykład oferta bazy noclegowej oraz propozycje/zaproszenia przysyłane ze strony różnych regionów i rejonów tego kraju, służące lepszemu jego poznawaniu. Liczne hotele starają się zapewnić małym uczestnikom jak najbardziej udogodnione warunki pobytu, udostępniając na przykład sale, gdzie maluchy mogą same stworzyć własne stroje na popołudniowy bal przebierańców w pobliskim zamku, czy też przeżyć przed pójściem spać czar bajki w teatralnym przedstawieniu.

Inne referaty oraz prywatne obserwacje autorki wykazały, że dla Słowaków wychowanie estetyczne jest sprawą oczywistą i odbywa się w sposób bardzo naturalny. To, o czym w Polsce się teoretyzuje, tam na Słowacji nie tylko, że się realizuje, lecz ma także swoją tradycję, na przykład „Wychowanie dramatyczne”. Tego typu forma oddziaływania pedagogicznego należy w Polsce do rzadkości, brak jej u nas także naukowych fundamentów, niemniej jej skuteczność domaga się wdrażania również w polskich warunkach. To również właśnie mogłoby być perspektywą rozwojową dla nowych kierunków akademickich.

Przykładem integracyjnej roli teatru jest rozwiązanie zaproponowane i przeprowadzone $\mathrm{w}$ ramach zakończenia etapu przedszkolnego i przejścia do etapu szkolnego - to jest zapoznania się byłych przedszkolaków i ich rodziców z przyszłymi nauczycielami. Praktyka pedagogiczna kolegów i koleżanek ze Słowacji podpowiada teatr jako odpowiednie miejsce na spotkanie i rozpoczęcie dalszej znajomości dzieci i ich wychowawców. Dr D. Kollarová opowiadała o jednym z nich. Rok szkolny na Słowacji rozpoczyna się we wrześniu, dlatego właśnie jeszcze w sierpniu zorganizowano takie spotkanie w teatrze. Najpierw rodzice i dzieci obejrzeli spektakl w wykonaniu przyszłych nauczycieli, następnie zaś odbyło się osobiste spotkanie. Każde z dzieci oraz każdy z rodziców, którzy weszli do teatru otrzymało znaczek. Taki sam znaczek miał wychowawca grupy, do której miało wraz z rozpoczęciem roku szkolnego trafić dziecko. W ten sposób wszyscy wiedzieli, jak mają siebie szukać i gdzie się kierować, a znaczek na pewno pozostał miłą pamiątką tego pierwszego spotkania.

W słowackim systemie szkolnictwa funkcjonują tak zwane „Szkolne Kluby Dzieci”. Jest to miejsce i forma, które nie tylko sprzyja zagospodarowaniu

${ }^{1}$ Film został nakręcony kamerą video, będącą wyposażeniem przedszkola, natomiast piosenki do filmu nagrano w studio. 
wolnego czasu dziecka, lecz również pozwala prowadzącemu realizować funkcje wychowawcze. Bardzo dużo dzieci uczestniczy w tych zajęciach, które odbywaja się na terenie szkoły. Rodzice deklarują, na jakie zajęcia czy do jakiej sekcji będa należały ich dzieci - czy będzie to sekcja tańca, śpiewu, teatru, czy jakaś inna. Pieniądze na tego typu aktywność pozyskiwane są od ministerstwa. Zajęcia te odbywają się raz w tygodniu - każde w inny dzień, niemniej wymiar czasowy jest tutaj ograniczony tylko dolną granicą - zajęcia te kończą się zazwyczaj około godziny $16: 30$, bo tak odbierają ze szkoły swoje dzieci rodzice. Gdy zaś chodzi o rozpoczęcie zajęć, to w zależności od tego, o której godzinie dziecko kończy lekcje, zaraz po nich może udać się do swojej sekcji. Nauczyciel będzie tam na nie już czekał.

Ciekawy referat, zaprezentowany przez mgr. E. Kováčová, dotyczył systemu "Centrum Wolnego Czasu” (odpowiedniki naszych Domów Kultury) w Puchovie, który nie czynił przedziału wiekowego, lecz w poszczególnych sekcjach łączył zarówno dzieci, młodzież, jak i seniorów. Rezultatem takiego układu było i jest inspirujące oraz mobilizujące oddziaływanie starszego pokolenia na młodsze, dające pomoc w pokonywaniu lenistwa młodych ludzi. Prelegentka podkreślała, że takie właśnie miejsca, jak to, sprzyjają także odkrywaniu pedagogicznych talentów dzieci. To, co w szkole jest obowiązkiem, tam traktowane jest jako przyjemność. W ten sposób dzieci bez oporu, lecz z własnej inicjatywy wdrażają się w system porządku, co odzwierciedla zachowanie dorosłego pokolenia Słowaków oraz ogólna sytuacja kulturowo-obyczajowa tego kraju - tam jest po prostu porządek, na ulicach czysto, a w ludziach nie ma agresji, lecz łagodność. Jeszcze w Trnavie autorka sprawozdania, podążając na pokonferencyjne przyjęcie, natknęła się na jedno z takich centrów, którego nazwa - Kalokagatia - pozostaje na pewno wymowna.

Jakkolwiek starsze pokolenie Słowaków narzeka, że współczesna młodzież nieszczególnie interesuje się folklorem, który na Słowacji ma rangę wartości narodowej, w porównaniu z sytuacją w Polsce, sytuacja na Słowacji jest bardziej niż optymistyczna: w każdym mieście znaleźć można co najmniej 3-4 działające prężnie zespoły folklorystyczne. O tym, jak prężnie, mogli przekonać się uczestnicy konferencji w części nieoficjalnej, podczas spotkania na kolacji, gdzie został zaproszony właśnie taki dziecięcy zespół. Najstarsze z tych dzieci mogło być najwyżej w drugiej klasie szkoły podstawowej. Dzieci nie tylko występowały w strojach regionalnych, lecz także śpiewały oraz grały na instrumentach. Ich miła obecność oraz pragnienie uprzyjemnienia nam czasu smakowały niczym danie główne.

Ogromna życzliwość naszych braci Słowian sprawia, że konferencje na Słowacji są zawsze wspaniała intelektualną przygodą. Pracownikom Wydziału Pedagogicznego Uniwersytetu w Trnavie bardzo zależy na dalszej współpracy z ośrodkami w Polsce. 